\title{
Hypertensive Patients: Self-Care Management Practices in Al-Taif, KSA
}

\author{
Dalal M Neminqani ${ }^{1}$, Etemad AA El-Shereef ${ }^{2}$, Maha M AL Thubiany ${ }^{4}$ \\ ${ }^{1}$ Associate Professor \&Consultant of Pathology and Cytopathology, MD,FRCPATH,IFCAP,FIAC,FPATHKSU, College of Medicine, Taif \\ University \\ ${ }^{2}$ Professor of Public Health and Community Medicine, Taif Medical College, Taif University, KSAand Faculty of Medicine, Assiut \\ University, Egypt \\ ${ }^{3}$ Sixth year student, Medical College, Taif University, KSA
}

\begin{abstract}
This descriptive cross sectional study aimed at determining the level of self-management practices and to identify its associated factors among patients with hypertension at King Abdul Aziz Hospital and Al Hada Military hospital at al Taif City. One hundred and twenty four subjects were included. The research tool was a questionnaire consisted of demographic and health related characteristics data assessment form and hypertension self- management behaviors questionnaire. Frequencies, means, standard deviations and analytic tests (Chi Square and T test) were used for data analysis. The results showed that an overall self-management behavior with hypertension was at moderate level (2.22 \pm 0.528$)$. For five sub-dimensions of self-management, the means of selfintegration, self- regulation, interaction, self-monitoring and adherence, were also at the moderate level. Adherence to recommended regimen had the highest score (2.45 \pm 0.48$)$ followed by Self-monitoring (2.39 \pm 0.69$)$.Women had significantly higher scores than men $2.47 \pm 0.40$ versus $2.08 \pm 0.54),(P=0.000)$. Middle aged and young adults had significantly higher self-management scores than older adults $(P=0.010)$. University educated subjects had higher self-management score than less educated $(P=0.025)$. Subjects who live in rural areas had insignificantly lower self-management behavior scores than those lived in urban areas $(P=0.931)$. In addition the time since diagnosis was found to be significant $(P=0.038)$. This study offers proof that among Saudi patients with hypertension, there is a chance for improving their self-management behaviors. The study suggested that, antihypertensive therapy must take into consideration the patient's awareness of the health-care provider's advice and instructions, factors that may improve self-management behaviors, and the possibility that the patient will adhere to recommendations
\end{abstract}

Keywords: Hypertension, self- management practices, factors affecting self-management

\section{Background}

Kearney and colleagues (2005) reported that, High blood pressure, or hypertension, is the primary and most common risk factor for heart disease, stroke and renal diseases. Hypertension affects more than a quarter of the global adult population comprising Kingdom of Saudi Arabia (KSA). It is projected in year 2025 to increase by $24 \%$ in developed countries and $80 \%$ in developing countries.It is expected that one in six people globally, or closely one billion, are affected by high blood pressure, and it is projected that this number will increase to 1.5 billion by 2025 .

Contrasting to most diseases, high blood pressure has no symptoms and is therefore called the ,silent killer". The World Health Organization (2002) also stated that high blood pressure is the chiefimportant cause of cardiovascular death. High blood pressure is prevailing in every part of the world, in every area of any nation and in every community. It affects the rich and the poor, the young and the old, men and women, urban and rural populations, and the educated and illiterate alike. The only way to settle the presence of hypertension is by assessing one"s blood pressure.

The rise in hypertension prevalence will usually lead to increases in the incidence of cardiovascular diseases and their consequences, which rises the load on health care systems (Chen, and L. Lipscombe, 2008) ${ }^{3}$. National surveys of prevalence, awareness, treatment, and control displayed that many hypertensives were ignorant of their disease, many of the alert were not on treatment, and many of the treated are not controlled principally in developing countries (Al-Nozha et $\mathrm{al}^{4}$., 2006 and Ibrahim et al., 1995)

Hypertension remains the cardinal atherosclerotic risk factor leading to early death. The monitoring of hypertension remains challenging, despite its ease of diagnosis, the easiness of blood pressure monitoring and the wide accessibility of a number of effective antihypertensive drugs with excellent safety profiles (Wright et al., 2009) ${ }^{6}$. Based on these concerns, self-care of hypertension - both in terms of monitoring and treatment would appear to be a practical option. Monitoring of blood pressure (as opposed to taking antihypertensive therapy in the absence of baseline blood pressure assessment) still appears to be a required step in the diagnosis and management of hypertension (Fehey et al., $2006)^{7}$.

Despite the presence of several useful pharmacologic and non-pharmacologicmethods to hypertension management, hypertension control is still poor, with less controlled blood pressure witnessed. Hypertension self-management behaviors comprisingmedication adherence, self-blood pressure monitoring, and lifestyle modificationsinvolving diet, exercise, and tobacco are critical components of recommendedhypertension treatment and have been associated with significant improvements inhypertension control (Giles et al., 2007) ${ }^{8}$.

Studies evaluating hypertensive patients" perceptions of causes prompting their self-management have demonstrated

\section{Volume 4 Issue 12, December 2015}




\section{International Journal of Science and Research (IJSR) \\ ISSN (Online): 2319-7064 \\ Index Copernicus Value (2013): 6.14 | Impact Factor (2014): 5.611}

that obstacles are multifactorial. Studies have shown that family members often play a vital role in patients ${ }^{\text {ee }}$ hypertension self-management, including providing support with food choice and preparation, helping patients to follow the behavioral recommendations (for example, smoking cessation), and supporting patients with medication and medical appointment adherence. Family members may also play a central role in easing patient-provider thoughts about hypertension care (Wassertheil et al, 2004) ${ }^{9}$.

Understanding Saudi patients ${ }^{\text {ee }}$ perceived self-management of hypertension could offer insights into a range of vital targets for interferences to increase hypertension control.

\section{Objective of the Study}

The aim of this study is:

1) To identify the level of self-management behavior among patients with hypertension.

2) To examine factors related to self-management among patients with hypertension.

\section{Subjects and methods:}

\section{Study Design:}

This study was a descriptive cross sectional study aiming at examining the level of self- management behavior among patients with hypertension in Al- Taif- KSA and to recognizerelatedfactors.

\section{Study Setting:}

This study was conducted at King AbdulAziz hospital which belong to Ministry of Health and Al Hada Military Hospital.

\section{Population and Sample:}

Non-probability convenient sampling method was followed. The target population of this study was a sample of patients of hypertension aged more than 18 years who attended outpatient clinics during the study period.

\section{Instrumentation:}

The instrument was a structured questionnaire developed after extensive reviewing of the literature. It composed of two parts: Demographic and Health associated data assessment tool; and forty questions, Hypertension SelfManagement Behavior questionnaire which modified by Nilmanat K and AkhterN (2010) ${ }^{10}$ from an existing tool (Lin et al, 2008) and used in their study Self-management among patient with hypertension in Bangladesh.

\section{Part I:}

Demographic and health related data assessment form:

Demographic data comprised: age, gender, marital status, educational level, economic status, residency, number of family members, and time since being diagnosed and type of payment for treatment. The health related Data Assessment Form included clinical significant characteristics comprising: body weight, smoking history, systolic and diastolic blood pressure measurement.

\section{Part II:}

Hypertension Self-Management Behavior Questionnaire: The hypertension self-management questionnaire consisted of 40 items addressing different aspects of self- management for the illness. These included:

Self- integration (13 items) which denotes a patient"s capability to integrate health care to daily lives through activities such as diet, exercise, weight control, smoking cessation and stress management.; self-regulation (9 items) which reveal patient's self-regulation of their behaviors through self-monitoring of body signs and symptoms and taking actions based on these changes.interaction with health professionals and significant others ( 9 items) about level of cooperation with health care workers and significant others; Self- monitoring (4 items) which is concerned with the monitoring of blood pressure at home for detecting blood pressure levels in order to modify self- care activities and adherent to recommended regimen (5 Items) which refers to patients adherence to prescribed anti-hypertensive medications and clinic visits.

The subject asked to rate each item to show the regularity which they do the self-management practices. Items then scored on a 4 - point scale ranging from 1 (never) to 4 (always). The self- management scores divided into three levels: low, moderate and high. The score of 1-2 means low level of self- management, scores of 2-3 means moderate level of self- management and 3-4 means high level of selfmanagement.

\section{Data Collection procedure:}

The data collection procedure consisted of two phases: preparation phase and implementation phase.

\section{Preparation phase:}

Getting permission from the Research Ethics Committee of the faculty of Medicine of Al- Taif University. Preparation of the structured questionnaire by the researcher. The permission of King Abdul Aziz Hospital and Al-Hada hospital was obtained. Also, written consent had been obtained from each patient.

\section{Implementation phase:}

The researcher contacted the subjects, clarifying the aims of the research and taking written consent. Data collected by the researcher through direct personal interview with the target patients in the outpatient clinics. Data was collected through the period from June 2015 to October 2015.

\section{Data analysis:}

The data was coded and data entry was done using SPSS version 22. Frequencies, percentages, means and standard deviation were calculated. Inferential statistics such as independent $\mathrm{t}$ - test and Chi- squarewere used for testing factors related to Self- management.

\section{Results}

One hundred and twenty four patients from King Abdul Aziz hospital and El Hada Military hospital in Al Taif City were included in the study.

\section{Volume 4 Issue 12, December 2015}




\section{International Journal of Science and Research (IJSR) \\ ISSN (Online): 2319-7064 \\ Index Copernicus Value (2013): 6.14 | Impact Factor (2014): 5.611}

Table (1) presented the demographic characteristics of the studied participants. Mean age of the subjects was 59.3 \pm 13.43. It was $57.3 \pm 13.6$ for men and $62.7 \pm 12.6$ for women.

A total $79(63.7 \%)$ were men and $45(36.3 \%)$ were women. Fifty seven (46.0\%) participants were illiterate and only 19 $(15.3 \%)$ had a university education. There were 23 (18.6\%) employed, 37 (29.8\%) unemployed and 64 (51.6\%) retired.

Table (2) shows that the majority of participants $(60.5 \%)$ mentioned that their monthly income is just sufficient, in $(24.2 \%)$, monthly income is not sufficient and may borrow and in (15.3\%) monthly income is sufficient and saving.

The mean number of family members was $7.7 \pm 3.5$. The majority of patients $111(89.5 \%)$ were from urban area.

Table (3) presented health related characteristics of the study participants. The mean systolic blood pressure was $140.2 \pm$ $23.7 \mathrm{mmHg}$ and mean diastolic blood pressure was $80.7 \pm$ $19.5 \mathrm{mmHg}$.

The mean body weights of studied subjects were $80.6 \pm 20.9$ $\mathrm{kg}$. According to body mass index classification of WHO, most of participants were obese $(63.7 \%), 20 / 2 \%$ were overweight, $12.1 \%$ were normal and $4.0 \%$ were underweight.

Most of patients (73.4\%) had known their diagnosis as hypertensive for more than five years. $41.1 \%$ of participants were nonsmokers, $45.2 \%$ stopped smoking and $13.7 \%$ continue smoking.

Twenty (16.1\%) of participants had no comorbidity, $33.9 \%$ had coronary artery disease, $29.0 \%$ diabetes mellitus, $8.1 \%$ chronic kidney disease, $4.0 \%$ stroke and $8.9 \%$ had more than one co-morbid condition.

Self- management behavior of study subjects were summarized in table (4). The categories of self- management were as follow:

The mean score for adherence to recommended regimen was the highest $(2.45 \pm 0.48)$ and it was followed by monitoring the disease (2.39 \pm 0.69$)$. As regard self-regulation, the mean score was $2.27 \pm 0.57$ followed by interaction with professional and significant others $(2.24 \pm 0.55)$. Lastly, the mean score was $2.10 \pm 0.33$ for self- integration behavior.
The classified general levels of all sub-groups of selfmanagement behavior were at moderate level.

\section{According to table (5): Five highest percentage of always} performed behaviors

1) Recognizing signs and symptoms of high blood pressure (2.68 \pm 0.64$)$, Moderate level.

2) Checking blood pressure or visiting doctor to check blood pressure when expecting signs and symptoms of high blood pressure (2.59 \pm 0.77$)$, Moderate level.

3) Strictly taken hypertension medication $(2.59 \pm 0.71)$, Moderate level.

4) Taking the right amount of antihypertension medication (2.55 \pm 0.77$)$, Moderate level.

5) Thinking that hypertension is part of life (2.55 \pm 0.71$)$, Moderate level.

\section{And five highest percentage of never/sometimes} performed behaviors were:

1) excerise to reduce weight $(1.47 \pm 0.64)$, Poor level.

2) Follow doctor advice regarding blood pressure control $(1.62 \pm 0.86)$, Poor level.

$3)$ Reducing amount of food per meal $(1.88 \pm 0.78)$, Poor level.

4) eating fruits, vegetables, grains, and beans more than before $(2.02 \pm 0.89)$, Moderate level.

5) Trying to control stress (2.02 \pm 0.93$)$, Moderate level.

Table (6) shows risk factors affecting self-management behaviors among hypertensive patients. It was found that young $(2.60 \pm 0.37)$ and middle aged patients $(2.30 \pm 0.42)$ had significantly higher score than older age $(2.10 \pm 0.58)$ and $(\mathrm{P}=0.010)$. Women $(2.47 \pm 0.40)$ had significantly higher self- management score than men $(2.08 \pm 0.54)$ and $(p=0.000)$.

Patients who diagnosed for more than 5 years had significantly higher self-management score $(2.28 \pm 0.51)$ than those who diagnosed for less than five years $(2.06 \pm$ $0.55)$ and $(\mathrm{P}=0.038)$.

It was found that patient who had enough income had insignificantly higher sore than others $(p=0.931)$. Also, patients who live in urban areas had insignificant higher score than patients who live in rural areas $(\mathrm{p}=0.931)$. 


\section{International Journal of Science and Research (IJSR) \\ ISSN (Online): 2319-7064}

Index Copernicus Value (2013): 6.14 | Impact Factor (2014): 5.611

Table 1: Demographic characteristics of the studied participants

\begin{tabular}{|c|c|c|c|c|c|c|}
\hline variables & $\begin{array}{c}\text { Males } \\
\mathrm{N}=(79)\end{array}$ & $\begin{array}{c}\% \\
63.7 \% \\
\end{array}$ & $\begin{array}{l}\text { Females } \\
\mathrm{N}=(45)\end{array}$ & $\begin{array}{c}\% \\
36.3 \% \\
\end{array}$ & $\begin{array}{c}\text { No. } \\
\text { (124) }\end{array}$ & $\begin{array}{c}\% \\
100.0 \\
\end{array}$ \\
\hline $\begin{array}{l}\text { Age: } \\
\text { Less than } 40 \\
40- \\
60^{+}\end{array}$ & $\begin{array}{c}6 \\
38 \\
35\end{array}$ & $\begin{array}{c}7.6 \\
48.1 \\
44.3\end{array}$ & $\begin{array}{c}2 \\
14 \\
29\end{array}$ & $\begin{array}{c}4.4 \\
31.1 \\
64.4\end{array}$ & $\begin{array}{c}8 \\
52 \\
64\end{array}$ & $\begin{array}{c}6.5 \\
41.9 \\
51.6\end{array}$ \\
\hline Mean \pm SD & \multicolumn{2}{|c|}{$57.3 \pm 13.6$} & \multicolumn{2}{|c|}{$62.7 \pm 12.6$} & \multicolumn{2}{|c|}{$59.3 \pm 13.43$} \\
\hline $\begin{array}{l}\text { Marital Status: } \\
\text { Single } \\
\text { Divorced } \\
\text { Married } \\
\text { Widow } \\
\end{array}$ & $\begin{array}{c}3 \\
3 \\
58 \\
15 \\
\end{array}$ & $\begin{array}{c}3.8 \\
3.8 \\
73.4 \\
19.0 \\
\end{array}$ & $\begin{array}{c}3 \\
3 \\
35 \\
4 \\
\end{array}$ & $\begin{array}{c}6.7 \\
6,7 \\
77.8 \\
8.9 \\
\end{array}$ & $\begin{array}{c}6 \\
6 \\
93 \\
19 \\
\end{array}$ & $\begin{array}{c}4.8 \\
4.8 \\
75.0 \\
15.3 \\
\end{array}$ \\
\hline $\begin{array}{l}\text { Educational level: } \\
\text { No formal education } \\
\text { Elementary } \\
\text { Secondary } \\
\text { university }\end{array}$ & $\begin{array}{l}27 \\
18 \\
19 \\
15\end{array}$ & $\begin{array}{l}34.2 \\
22.8 \\
24.1 \\
19.0\end{array}$ & $\begin{array}{c}30 \\
9 \\
2 \\
4\end{array}$ & $\begin{array}{c}66.7 \\
20.0 \\
4.4 \\
8.9\end{array}$ & $\begin{array}{l}57 \\
27 \\
21 \\
19\end{array}$ & $\begin{array}{l}46.0 \\
21.8 \\
16.9 \\
15.3\end{array}$ \\
\hline $\begin{array}{l}\text { Employment status } \\
\text { Employed } \\
\text { Unemployed } \\
\text { retired }\end{array}$ & $\begin{array}{c}13 \\
2 \\
64\end{array}$ & $\begin{array}{c}16.5 \\
2.5 \\
81.0\end{array}$ & $\begin{array}{c}10 \\
35 \\
0\end{array}$ & $\begin{array}{l}22.2 \\
77.8 \\
0.00\end{array}$ & $\begin{array}{l}23 \\
37 \\
64\end{array}$ & $\begin{array}{l}18.6 \\
29.8 \\
51.6\end{array}$ \\
\hline
\end{tabular}

Table 2: Family characteristics of the studied participants

\begin{tabular}{|l|c|c|}
\hline & No. & $\%$ \\
\hline Monthly income: & & \\
$1-\quad$ Is sufficient with saving & 79 & 15.3 \\
$2-\quad$ Just sufficient & 30 & 60.5 \\
$3-\quad$ Is not sufficient and may borrow & 111 & 24.2 \\
\hline Residential area: & 13 & 89.5 \\
$1-\quad$ Urban & & 10.5 \\
$2-\quad$ Rural & & $7.7 \pm 3.5$ \\
\hline Number of family members: & \\
Mean \pm SD & \\
\hline
\end{tabular}

Table 3: Health related characteristics of study participants

\begin{tabular}{|c|c|c|}
\hline Variable & & \\
\hline $\begin{array}{l}\text { Mean blood pressure/mmHG } \\
\text { Systolic } \\
\text { Diastolic }\end{array}$ & \multicolumn{2}{|c|}{$\begin{array}{l}140.2 \pm 23.7 \\
80.7 \pm 19.5\end{array}$} \\
\hline $\begin{array}{l}\text { Mean body weight: } \\
-\quad \text { Mean } \pm \text { SD } \\
\end{array}$ & \multicolumn{2}{|c|}{$80.6 \pm 20.9$} \\
\hline $\begin{array}{l}\text { BMI classification: } \\
\text { Underweight }\end{array}$ & 5 & 4.0 \\
\hline - Normal & 15 & 12.1 \\
\hline - $\quad$ Overweight & 25 & 20.2 \\
\hline - $\quad$ obese & 79 & 63.7 \\
\hline $\begin{array}{c}\text { Time since diagnosis } \\
<5 \text { years } \\
\geq 5 \text { years }\end{array}$ & $\begin{array}{l}33 \\
91\end{array}$ & $\begin{array}{l}26.6 \\
73.4\end{array}$ \\
\hline $\begin{array}{l}\text { Smoking history: } \\
\text { Never } \\
\text { Yes but quit now } \\
\text { Continue to smoke }\end{array}$ & $\begin{array}{l}51 \\
56 \\
17 \\
\end{array}$ & $\begin{array}{l}41.1 \\
45.2 \\
13.7 \\
\end{array}$ \\
\hline $\begin{array}{c}\text { Family history of Diabetes: } \\
\text { Yes } \\
\text { No } \\
\end{array}$ & $\begin{array}{l}57 \\
67 \\
\end{array}$ & $\begin{array}{l}46.0 \\
54.0\end{array}$ \\
\hline $\begin{array}{l}\text { Comorbidity: } \\
\text { No Comorbidity } \\
\text { Coronary artery disease } \\
\text { Diabetes mellitus } \\
\text { Chronic kidney disease } \\
\text { Stroke } \\
\text { More than one condition }\end{array}$ & $\begin{array}{c}20 \\
42 \\
36 \\
10 \\
5 \\
11 \\
\end{array}$ & $\begin{array}{c}16.1 \\
33.9 \\
29.0 \\
8.1 \\
4.0 \\
8.9 \\
\end{array}$ \\
\hline
\end{tabular}

Volume 4 Issue 12, December 2015 


\section{International Journal of Science and Research (IJSR) \\ ISSN (Online): 2319-7064}

Index Copernicus Value (2013): 6.14 | Impact Factor (2014): 5.611

Table 4: Level of self-management behavior among studied participants

\begin{tabular}{|l|c|c|}
\hline Variable & Mean \pm SD & General Level \\
\hline 1-Sele-integration & $2.10 \pm 0.33$ & Moderate \\
\hline 2-Self-regulation & $2.27 \pm 0.57$ & Moderate \\
\hline 3-Interaction with professional and significant others & $2.24 \pm 0.55$ & Moderate \\
\hline 4-Self-monitoring & $2.39 \pm 0.69$ & Moderate \\
\hline 5-Adherence to recommended regimens & $2.45 \pm 0.48$ & Moderate \\
\hline Total & $2.22 \pm 0.528$ & Moderate \\
\hline
\end{tabular}

Table 5: Five items with higher percentage of always performed and highest percentage of never performed behaviors

\begin{tabular}{|l|l|l|}
\hline \multicolumn{1}{|c|}{ Variable } & Mean \pm SD. & level \\
\hline Five highest percentage of always performed behaviors & & \\
1-Recognizing signs and symptoms of high blood pressure & $2.68 \pm 0.64$ & Moderate \\
2-Checking blood pressure or visiting doctor to check blood pressure when expecting signs and symptoms & $2.59 \pm 0.77$ & Moderate \\
of high blood pressure & $2.59 \pm 0.71$ & Moderate \\
3-Strictly taken hypertension medication & $2.55 \pm 0.77$ & Moderate \\
4-Taking the right amount of antihypertension medication & $2.55 \pm 0.71$ & Moderate \\
5- Thinking that hypertension is part of life & & \\
\hline Five highest percentage of never performed behaviors & $1.47 \pm 0.64$ & Poor \\
1-excerise to reduce weight & $1.62 \pm 0.86$ & Poor \\
2-Follow doctor advice regarding blood pressure control & $1.88 \pm 0.78$ & Poor \\
3-Reducing amount of food per meal & $2.02 \pm 0.89$ & Moderate \\
4-eating fruits, vegetables, grains, and beans more than before. & $2.02 \pm 0.93$ & Moderate \\
5-Trying to control stress &
\end{tabular}

Table 6: Risk factors relating to Self-management behavior

\begin{tabular}{|c|c|c|c|}
\hline & Mean \pm SD & F test/ Ttest & $\mathrm{P}$ value \\
\hline $\begin{array}{l}\text { Age: } \\
20-40 \\
40-60 \\
60+ \\
\end{array}$ & $\begin{array}{l}2.60 \pm 0.37 \\
2.30 \pm 0.42 \\
2.10 \pm 0.58\end{array}$ & 4.79 & 0.010 \\
\hline $\begin{array}{l}\text { Gender: } \\
\text { Males } \\
\text { Females }\end{array}$ & $\begin{array}{l}2.08 \pm 0.54 \\
2.47 \pm 0.40 \\
\end{array}$ & 18.35 & 0.000 \\
\hline $\begin{array}{l}\text { Education: } \\
\text { No formal education } \\
\text { Elementary education } \\
\text { Secondary education } \\
\text { University }\end{array}$ & $\begin{array}{l}2.09 \pm 0.50 \\
2.10 \pm 0.56 \\
2.17 \pm 0.56 \\
2.55 \pm 0.43 \\
\end{array}$ & 3.23 & 0.025 \\
\hline $\begin{array}{l}\text { Income: } \\
\text { Enough and safe } \\
\text { Just enough } \\
\text { Do not enough and borrow }\end{array}$ & $\begin{array}{l}2.28 \pm 0.60 \\
2.24 \pm 0.51 \\
2.16 \pm 0.53\end{array}$ & 0.362 & 0.697 \\
\hline $\begin{array}{l}\text { Residential area: } \\
\text { Urban } \\
\text { Rural }\end{array}$ & $\begin{array}{l}2.22 \pm 0.54 \\
2.21 \pm 0.41\end{array}$ & 0.007 & 0.931 \\
\hline $\begin{array}{l}\text { Time since diagnoses: } \\
\text { Less than } 5 \text { years } \\
5 \text { years and more }\end{array}$ & $\begin{array}{l}2.06 \pm 0.55 \\
2.28 \pm 0.51\end{array}$ & 4.377 & 0.038 \\
\hline $\begin{array}{l}\text { Hospital: } \\
\text { Al- Hada Military hospital } \\
\text { King Abdul Aziz Hospital }\end{array}$ & $\begin{array}{c}2.28 \pm 0.562 \\
2.18 \pm 0.50\end{array}$ & 1.007 & 0.318 \\
\hline
\end{tabular}

\section{Discussion}

According to World Health Organization (WHO, 2014) ${ }^{11}$, Saudi Arabia, one of the largest countries in the Middle East, has massive oil reserves, and the subsequent wealth has accompanied in an era of socio economic transition. Naturally, the profits to health and lifestyle in the general population of KSA have been remarkable.

Alternatively, this transition has brought with it new opposing health behaviors. For example, growing availability of food, such as meat by $313 \%$ and oil/fat by
$200 \%$ between 1974 and 1995, has resulted in a per capita increased consumption of energy from 1,807 to 3,128 $\mathrm{kcal} /$ day in the same time span, ( Madani et al., 2000) ${ }^{12}$, while the recommended daily intake in KSA is 2,100 kcal. (Al-Kanhal et al., 1998) ${ }^{13}$. According to Euromonitor International (2014) ${ }^{14}$, soft drink drinking and restaurant eating have amplified in KSA, and the rate of sedentary lifestyle of Saudi nationals across varying age groups has been estimated to be from $43.3 \%$ to $99.5 \%$. Consequently, obesity is increasing in both adults and children in the Kingdom (Abalkhail, 2000) ${ }^{15}$ along with a simultaneous

\section{Volume 4 Issue 12, December 2015}




\section{International Journal of Science and Research (IJSR) \\ ISSN (Online): 2319-7064 \\ Index Copernicus Value (2013): 6.14 | Impact Factor (2014): 5.611}

increase in type 2 diabetes, hypertension and hypercholesterolemia (El-Hazmi and Warsy2000) ${ }^{16}$.

The Saudi Ministry of Health (MOH) is a government department whose responsibility is to develop a network of primary healthcare centers and confirm that the Saudi population has acceptable access to care (Almalki et al., $2011)^{17}$. An important development has been a comprehensive referral system through a broad base of general and specialist hospitals. (Aldossary et al., 2008) ${ }^{18}$. The Saudi government has channeled substantial financial resources into the enhancement of healthcare and social services (Al-Yousuf et al., 2002) ${ }^{19}$. Their objective is to deliver free healthcare for Saudi nationals and colonials employed in the public sector.

Saudi Arabia country seeks to create a maintainable, organized health development process to all its citizens, including prevention of common diseases and their complications, to ensure public wellbeing. And so, the government is keen to focus on generating mechanisms with a view to improve and implement an adequate range of comprehensive health services programs through the Ministry of Health and other related health institutions.As a result, the Ministry of Health has adopted many health policies and programs to prevent, detect, evaluate, and treat non-communicable diseases, one of which is HTN. This disease affects $20 \%$ of the Saudi population, children and adults alike, and is the leading cause of $\mathrm{CV}$, cerebrovascular, and renal morbidities and mortalities (Saudi hypertension management guidelines, 2011) ${ }^{20}$.

The Saudi Hypertension Management Society (SHMS) plays an important role in translating Clinical Practice Guidelines (CPGs) and programs into practical plans of action, unified in a protocol for early finding and good management of this health problems and its complications. Another role for SHMS is the development of national awareness and educational programs addressed to healthcare professionals and the general public for primary prevention of HTN and the Metabolic Syndrome complex (Saudi hypertension management guidelines, 2011$)^{20}$.

The mean age of hypertension patients in this study was $59.3 \pm 13.43$. It was $57.3 \pm 13.6$ for men and $62.7 \pm 12.6$ for women (table 1). More than half of subjects were above the age of sixty $(51.6 \%)$. These results is in accordance with many of other studies. Anderson (1999) showed in his study that increased age is associated with a significant increase in the prevalence of hypertension and especially of systolic hypertension after age 60 years. Also, Japan is a super-aged society in which the elderly aged over 65 years account for $23.3 \%$ of the population (in 2011) and those aged over 75 years account for $11.5 \%$. Hypertension increases with age, and, according to the National Health and Nutrition Survey of Japan $(2011)^{21}$ (Counter of Government statistics, 2013), hypertension is prevalent in $66 \%$ of those aged $65-74$ years and $80 \%$ of those aged over 75 years.

In this study $63.7 \%$ were men and $36.3 \%$ were women (table 1). These results are in consistent with Wiinber and colleagues (1995) ${ }^{22}$ who studied 352 normotensive (for age) Danish men and women, aged 20 to 79 years, and found that blood pressure increased with aging in both men and women, but that men had higher 24-hour mean blood pressure, by approximately 6 to $10 \mathrm{~mm} \mathrm{Hg}$, than did women, until the age of 70 to 79 years, when blood pressure was similar for men and women. Khoury and colleagues ${ }^{23}$ performed ambulatory blood pressure monitoring on 131 men and women, aged 50 to 60 years, and found that men had higher blood pressure than did women.

The results of this study displayed that (13.7\%) were smokers, $(45.2 \%)$ stopped smoking, and $(41.1 \%)$ were nonsmokers. The results of other studies showed that any independent chronic effect of smoking on blood pressure is insignificant. After adjustment for age, BMI, alcohol, and social class, they established only in older men significantly higher systolic blood pressure in heavy and moderate smokers than in never smokers while no such variances were perceived for diastolic blood pressure. The assumption of elevated systolic blood pressure, but not diastolic blood pressure, only in older men is an important new observation that is well-matched with effects expected in association with chronically enhanced atherogenesis in large capacitance vessels, with which smoking is associated and which yields isolated systolic hypertension (Fagori et al., 1996) ${ }^{24}$.

About three quarters of patients had known their diagnosis for five year or more. Only $16.1 \%$ reported that they had no other comorbidities. The majority conveyed that they have other morbidities as coronary artery disease, DM, chronic kidney diseases and stroke. These comorbidities are commonly found in hypertensive patients who have hypertension for few years (Smeltzer and Bare, 2004) ${ }^{25}$.

\section{Self-management behaviors:}

Self-management for people with chronic health problems is widely recognised as a required part of treatment. The patient is answerable for the day-to-day management of their illness (Lorig and Holman 2000) ${ }^{26}$.

Interventions using self-measurement of blood pressure (BP) have been shown to yield greater blood pressuredeclines than ordinary care using office-based BP measurement (Uhlig et al., 2013) ${ }^{27}$. Home BP is a significant interpreter of cardiovascular (CV) mortality and $\mathrm{CV}$ events and is probably superior to office BP as a predictor of target organ injury (Ward et al., 2012) ${ }^{28}$. In this study, adherence to recommended regimen domains which denotes patients' adherence to hypertension medications and clinic visits had the highest mean score $(2.45 \pm 0.48)$ compared to other dimensions. These results are in agreement with Kamel et al., $(1999)^{29}$ who reported that more than three quarters of chronic patients adhered well to the medical treatment. Similarly, our results are consistent with Kravitz et al., $(1993)^{30}$ who conveyed that $91 \%$ of their patients take medication as prescribed. In addition, Anderson and Fitzgerald $(1995)^{31}$ reported an even higher rate of compliance with medication regimen.

Adherence to medication was followed directly by selfmonitoring practice $(2.39 \pm 0.69)$ which is concerned with the home measuring of blood pressure for identifying blood pressure levels. Though, regardless of a call for routine

\section{Volume 4 Issue 12, December 2015}




\section{International Journal of Science and Research (IJSR) \\ ISSN (Online): 2319-7064 \\ Index Copernicus Value (2013): 6.14 | Impact Factor (2014): 5.611}

adoption of home BP monitoring in patients with identified or suspected hypertension, issued jointly in 2008 by the American Heart Association, the American Society of Hypertension, and the Preventive Cardiovascular Nurses Association, many physicians do not encourage patients to self-monitor. Recent hypertension management guidelines that acknowledge the worth of home measurement (selfmonitoring) of BP, (Mancia et al., 2013 ${ }^{32}$, National Clinical Guideline Center, 2014 33 and Canadian Hypertension Education Program (CHEP),2014) $)^{34}$ as well as guidelines focused totally on home BP monitoring, (Centers for Disease Control and Prevention, $2013^{35}$ and American Heart Association, 2014) ${ }^{36}$ consider home BP measurement as an assistant to conventional office BP measurement, the "gold standard" for screening, diagnosis, and management of hypertension.

Self-regulation practices which reflects self-monitoring of body signs and symptoms and taking actions according to these symptoms was $(2.27 \pm 0.57)$. In this study, all subjects has developed hypertension for more than one year and most of them had comorbidities. Therefore they had symptom experience related to high or low blood pressure. As a consequence they are able to notice any change in their blood pressure.

At a low level of practice were interaction with professional and significant others $(2.24 \pm 0.55)$ which is based on the concept that good health care involves collaboration with health care provider and significant others. It was followed by self- integration $(2.10 \pm 0.33)$ which refers to a patient ability to integrate health care into their daily lives to manage diet, exercise and stress. These results were not consistent with Kamel and his colleagues $(2003)^{37}$ in a study conducted in Egypt and concluded that almost all patients had high level of knowledge and practice of different desired self- care behavior.

Diet is considered as bakestone of any management plan for chronic diseases as diabetes and hypertension. In this study reducing amount of food per meal and eating fruits, vegetables, grains, and beans more than before were among the least practices to do. These results were in agreement with $\mathrm{Khattab}^{38}$ and his colleagues in a study conducted in Saudi Arabia (2010) and reported that compliance with diet was much worse than compliance to treatment.

Physical exercise is another important element in selfmanagement practices. Despite its significant importance, it has a low score in this study. These results were in common with Khattab study $(2010)^{38}$. This also occurs with some eastern and western studies of the world, where it has been observed that compliance with medical aspects of regimen as medication than with life style aspects of regimen (as diet and physical exercise) (Ammari, 2004) ${ }^{39}$.

According to Whitmer $(2008)^{40}$, the communication between the provider and the patient may show themore significant role in building patients ${ }^{\text {ee }}$ knowledge base, belief about treatment and self-confidence in management of illness. Most of nurses in Saudi Arabia are foreigners and speaking another language. Al-Shahri, 2002 ${ }^{41}$, reported that, There is a widespread gap in communication between the patient and nursing staff due to multiple factors such as language barriers and lack of cultural awareness. Although nonArabic-speaking nurses occasionally learn a few words of Arabic, this is not satisfactory to communicate efficiently in another language. "Knowing a smattering of a foreign language only allows one to make a fluent fool of oneself if the implicit meanings behind highly subtle linguistic symbols are not understood"( Ross, 2004) ${ }^{42}$. As a result, explainers are needed to enable communication between English-speaking staff and Arabic-speaking patients. In addition, selecting an interpreter of the patient's gender is likely to result in a more relaxed and competent interpretation process in an attentionto religion and culture

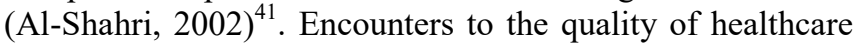
in Saudi Arabia are shown in the results of a patient satisfaction survey conducted at King Khalid University Hospital (KKUH) in Riyadh. The overall mean satisfaction percentage was $77 \%$ and the lowest score was for communication. With respect to communication, the lowest level of satisfaction was with nurses' consideration to patients' cleanliness, and for listening to and conversing with patients. (Al-Doghaither, 2000) ${ }^{43}$.

\section{Factors affecting self-management:}

As shown in table (6), this study showed that young and middle aged adults had significantly higher self-

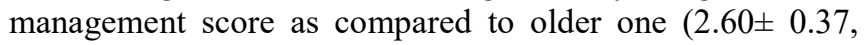
$2.30 \pm 0.42$ versus $2.10 \pm 0.58)$. Cognitive impairment usually occurs in old parsons and this affect their capability to communicate and understand the guidelines. Sinclair and colleagues $(2000)^{44}$ stated that elderly subjects with predominantly Type 2 diabetes mellitus display significant excess of cognitive dysfunction, associated with poorer ability in self-care and greater dependency. They stated that, routine screening of cognition in older subjects with chronic diseases is recommended. The cognitive deficit may make daily decision-making challenging by damaging the perception and interpretation of early symptoms and thinking and thereby delay early treatment implementation (Dickson, et al, 2007) ${ }^{45}$. This finding is not consistent with some preceding studies. Cognitive impairment leads to shortfalls in attention, learning, memory, executive functions, and psychomotor speed and may impair their ability to carry out self-care and adhere to treatment requirements. Such shortages may also compromise patients $^{\text {ee }}$ capacity to recognize worsening symptoms and make proper decisions about their health care (Malik et al., $2011)^{46}$.

In contrast to our results, Lee et al., $(2010)^{47}$ found that older patients with hypertension had healthier self-care behavior. In the present study it was found that females had significantly higher self- management behavior score as compared to males $(2.47 \pm 0.40$ versus $2.08 \pm 0.54)$. Chung et al., $(2006)^{48}$ found that women have more knowledge about disease than men. In addition, Yount et al., $(2004)^{49}$ established that women often report they visit providers and use medication more often than men.

In the present study $46 \%$ of patients had not received formal education. Most of them were illiterate. They were unable to read or understand the written instructions. University

\section{Volume 4 Issue 12, December 2015}




\section{International Journal of Science and Research (IJSR) \\ ISSN (Online): 2319-7064 \\ Index Copernicus Value (2013): 6.14 | Impact Factor (2014): 5.611}

respondents had significantly higher self-management behavior $(2.55 \pm 0.43)$ compared to those with no education $(2.09 \pm 0.5)$. These findings are in agreement with other studies which demonstrated that education is regarded as an essential prerequisite for self- management of a chronic disease. (Wejiman et al., 2003) ${ }^{50}$ also found that level of education was related to the frequency of self- management.

Length of time since diagnosis more than 5 years was associated with higher self-management $(2.28 \pm 0.51)$ compared to those with less than 5 years $(2.06 \pm 0.55)$. Accordingly, longer duration of hypertension was associated with improved self-management behavior. The finding of this study is consistent with a preceding study. Lee et al., $(2010)^{47}$ found a positive relationship between years of hypertension and self-care behavior. They stated that those with longer durations of hypertension might have had more knowledge opportunities available to them. It is possible that patients who have endured hypertension longer have learned more about managing hypertension.

Respondents who live in urban areas have insignificantly higher score than those live in rural areas. Also in this study income was insignificantly affect self- management behavior. This is inconsistent with Jerant et al., $(2005)^{51}$ who found that financial constraints and costs of care were the most common barriers to accessing self-management support resources. This is not a case in Saudi Arabia, It is one of the largest countries in the Middle East (WHO, $2014)^{11}$ has enormous oil reserves, and the resulting wealth has ushered in an era of socio economic transition. Naturally, the benefits to health and lifestyle in the general population of KSA have been remarkable. Currently the $\mathrm{MOH}$ is the major government provider and financer of health care services in Saudi Arabia, with a total of 244 hospitals (33 277 beds) and 2037 primary health care (PHC) centers. These services encompass $60 \%$ of thetotal health services in Saudi Arabia (Health statistical year book. Ministry of Health, 2009) $)^{52}$.

\section{Recommendations}

Antihypertensive therapy must take into attention the patient"s awareness of the health-care provider"s advice and prescriptions, factors that may impact self-management behaviors, and the likelihood that the patient will adhere to recommendations. Self-management principles should be incorporated into the treatment plan. All patients should be evaluated for obstacles to adherence and self-management, and referred for further counseling as wanted (to a nurse practitioner, registered nurse, registered dietitian, masters prepared social worker, pharmacist, physician assistant, or other professional).Patient and family education about antihypertensive therapy should be socially sensitive, sensitive to economic concerns, and based on the patient's level of understanding.

\section{Acknowledgment}

We would like to thank the members of research committee in King Abdul Aziz Hospital and Al Had Military hospital for their precise revision of the proposal and for all physicians who assisted us in data collection and facilitating the work.

\section{References}

[1] Kearney PM, Whelton M, Reynolds K, Muntner P, Whelton PK, He J. Global burden of hypertension: Analysis of worldwide data. Lancet. 2005; 365:217-23.

[2] World Health OrganizationWorld health report 2002 reducing risks, promoting healthy life. $<$ www.who.int/whr/2002/en>.

[3] Tu K, Chen Z, and Lipscombe L, "Prevalence and incidence of hypertension from 1995 to 2005: a population-based study," The Canadian Medical Association Journal, vol. 178, no. 11, pp. 1429-1435, 2008. View at Publisher . View at Google Scholar . View at Scopus.

[4] Al-Nozha M, Abdullah, M. R. Arafah et al., "Hypertension in Saudi Arabia," Saudi Medical Journal, vol. 28, no. 1, pp. 77-84, 2007. View at Google Scholar - View at Scopus

[5] Ibrahim M, Rizk H, Appel L, et al., "Hypertension prevalence, awareness, treatment, and control in Egypt. Results from the Egyptian National Hypertension Project (NHP)," Hypertension, vol. 26, no. 6, pp. 886890,1995

[6] Wright JT Jr, Probstfield JL, Cushman WC, et al; ALLHAT Collaborative Research Group. ALLHAT findings revisited in the context of subsequent analyses, other trials, and meta-analyses. Arch Intern Med.2009;169(9):832-842.

[7] Fahey T, Schroeder K, Ebrahim S. Interventions used to improve control of blood pressure in patients with hypertension. Cochrane Database Syst Rev. 2006;(4):CD005182.

[8] Giles T, Aranda JM, Jr, Suh DC, et al. Ethnic/racial variations in blood pressure awareness, treatment, and control. J Clin Hypertens (Greenwich) 2007;9(5):345354. [PubMed].

[9] Wassertheil-Smoller S, Shumaker S, Ockene J, et al. Depression and cardiovascular sequelae in postmenopausal women. The Women's Health Initiative (WHI) Arch Intern Med. 2004;164(3):289-298.

[10]Nilmanat K and Akhter N. Self-management among patient with hypertension in Bangladesh. Thesis (M.N.S., Nursing Science)--Prince of Songkla University, 2010. Captured at http://kb.psu.ac.th/psukb/handle/2010/8492.

[11] World Health Organization. (n.d.). Saudi Arabia. Available from: http://www.who.int/countries/sau/en/. [Last retrieved on 2014 Sep 28].

[12] Madani KA, Al-Amoudi NS, Kumosani TA. The state of nutrition in Saudi Arabia. Nutr Health 2000;14:17-31

[13] Al-Kanhal MA, Al-Mohizea IS, Al-Othaimeen AI, Khan MA. Nutritional evaluation of some legume-based dishes consumed in Saudi Arabia. Int J Food Sci Nutr 1998;49:193-7.

[14] Euromonitor International. (n.d.). Global Market Research and Analysis for Industries, Countries, and Consumers.

Available from:http:/www.euromonitor.com/. [Last retrieved on 2014 Sep 28]. 


\section{International Journal of Science and Research (IJSR) ISSN (Online): 2319-7064 \\ Index Copernicus Value (2013): 6.14 | Impact Factor (2014): 5.611}

[15] Abalkhail B. Overweight and obesity among Saudi Arabian children and adolescents between 1994 and 2000. East Mediterr Health J 2002;8:470-9.

[16] El-Hazmi MA, Warsy AS. Prevalence of overweight and obesity in diabetic and non-diabetic Saudis. East Mediterr Health J 2000;6:276-82.

[17] Almalki M, Fitzgerald G, Clark M. Health care system in Saudi Arabia: An overview. East Mediterr Health J 2011;17:784-93.

[18] Aldossary A, While A, Barriball L. Health care and nursing in Saudi Arabia. Int Nurs Rev 2008;55:125-8.

[19]Al-Yousuf M, Akerele TM, Al-Mazrou YY. Organization of the Saudi health system. East Mediterr Health J 2002;8:645-53.

[20] Saudi hypertension management guidelines. Saudi Hypertension Management Society report (2001) atwww.ssfcm.org/addon/files/hypertension.pdf

[21] Counter of Government statistics: [List of statistical tables] (in Japanese) http://www.estat.go.jp/SG1/estat/GL08020103.do?_toGL08020103 $\&$ listID $=000001108362 \&$ disp $=$ Other\&requestSender $=\bar{d}$ search. Accessed 18 May 2013. E-III

[22] Wiinber N, Hoegholm A, Christensen HR, Bang LE, Mikkelsen KL, Nielsen PE, Svendsen TL, Kampmann JP, Madsen NH, Bentzon MW. 24-h Ambulatory blood pressure in 352 normal Danish subjects, related to age and gender. Am J Hypertens. 1995;8:978-986.

[23] Khoury S, Yarows SA, O'Brien TK, Sowers JR. Ambulatory blood pressure monitoring in a nonacademic setting: effects of age and sex. Am J Hypertens. 1992;5:616-623.

[24]Fogari R, Zoppi A, Lusardi P, Marasi G, Villa G, Vanasia A. Cigarette smoking and blood pressure in a worker population: a cross-sectional study. J Cardiovasc Risk. 1996;3:55-59.

[25] Smeltezer, S.C. \& Barr, B.G. (2004). Bruna and studdarth 's text book of medical surgical nursing (10th ed.). Volume (2). Philadeplhine, Lippinott Willimas and Wilkins.

[26] Lorig, K. and Holman, H. Self-management education: context, definition, and outcomes and mechanism. First Chronic Disease Self-Management Conference: Sydney, NSW, Australia, August 2000, p.18

[27] Uhlig K, Patel K, Ip S, Kitsios GD, Balk EM. Selfmeasured blood pressure monitoring in the management of hypertension: a systematic review and meta-analysis. Ann Intern Med. 2013;159:185-194. Abstract

[28] Ward AM, Takahashi O, Stevens R, Heneghan C. Home measurement of blood pressure and cardiovascular disease: systematic review and meta-analysis of prospective studies. J Hypertens. 2012;30:449-456. Abstract

[29] Kamel NM, Badawy YA, El-Zeiny NA, Merdan IA. Socio-demographic determinants of management behavior of diabetic patients, part I: behavior of patients in relation to management of their disease. EMHJ. 1999; 5(5):967-973.

[30] Kravitz RL, Hays RD, Sherbourne CD, DiMatteo MR, Rogers WH, Ordway L, et al. Recall of recommendations and adherence to advice among patients with chronic medical conditions. Arch Intern Med.1993; 135(16): 1569-78.
[31] Anderson RM, Fitzgerald JT, Oh MS. The relationship between diabetes-related attitudes and patient's selfreported adherence. Diabetes Educ. 1993; 19(4):287-92.

[32] Mancia G, Fagard R, Narkiewicz K, et al. 2013 $\mathrm{ESH} / \mathrm{ESC}$ guidelines for the management of arterial hypertension: the Task Force for the Management of Arterial Hypertension of the European Society of Hypertension (ESH) and of the European Society of Cardiology (ESC). Eur Heart J. 2013;34:2159-2219. Abstract

[33] National Clinical Guideline Center. Hypertension: clinical management of primary hypertension in adults: NICE clinical guideline 127. London, UK: National Institute for Health and Clinical Excellence; 2011.http://www.nice.org.uk/guidance/cg127 Accessed October 20, 2014.

[34] Canadian Hypertension Education Program (CHEP). 2014 Recommendations for the Management of Hypertension. Markham, ON: Hypertension Canada; 2014.

[35]Centers for Disease Control and Prevention. SelfMeasured Blood Pressure Monitoring: Action Steps for Public Health Practitioners. Atlanta, GA: Centers for Disease Control and Prevention, US Department of Health and Human Services; 2013.

[36] American Heart Association. Home blood pressure monitoring. Updated September 11, 2014.http://www.heart.org/

[37] HEARTORG/Conditions/HighBloodPressure/Symptom sDiagnosisMonitoringofHighBloodPressure/HomeBlood-Pressure-Monitoring_UCM_301874_Article.jsp Accessed October 17, 2014.

[38] Kamel MH, Ismail MA, El-Deib AR, Khattab MS. Predictors of selfcare behavior in adults with type 2 diabetes mellitus in $\mathrm{Abu}$ Khalifa village, Ismailia, Egypt. Suez Canal Univ Med J. 2003; 6(2)-185-195.

[39] Khattab M, Khader YS, Al-Khawaldeh A, Ajlouni K. Factors associated with poor glycemic control among patients with Type 2 diabetes. J Diabetes Complications. 2010; 24(2):84-89. [DOI via Crossref] [Pubmed]

[40] Ammari F. Long-term complications of type 1 diabetes mellitus in the western area of Saudi Arabia. Diabetologia Croatica 2004; 33(2):59-63.

[41] Whitmer RA1, Gustafson DR, Barrett-Connor E, Haan MN, Gunderson EP, Yaffe K. Central obesity and increased risk of dementia more than three decades later. Neurology. 2008 Sep 30;71(14):1057-64. doi: 10.1212/01.wnl.0000306313.89165.ef. Epub 2008 Mar 26.

[42] Al-Shahri MZ. Culturally sensitive caring for Saudi patients. J Transcult Nurs 2002;13:133-8.

[43]Ross E, Deverell A. Psychosocial Approaches to Health, Illness and Disability: A Reader for Health Care Professionals. Pretoria: BPR Publishers; 2004

[44] Al-Doghaither AH. Inpatients satisfaction with nursing services King Khalid University Hospital, Riyadh, Saudi Arabia. J Family Community Med 2000;7:37-45.

[45] Sinclair AJ, Griling AJ and Bayer AJ. Cognitive dysfunction in older subjects with diabetes mellitus. Impact on diabetes self-management and use of care services. Diabetes research and clinical practice.2000, 50:203-212. 
[46]Dickson VV, Thacs N. and Riegel B. Cognitive influence on self-care decision making in persons with heart failure. Americaaan Heart Journal. 2007. 145:424431.

[47] Malik A. S., G. Giamouzis, V. V. Georgiopoulou et al., "Patient perception versus medical record entry of health-related conditions among patients with heart failure," The American Journal of Cardiology, vol. 107, no. 4, pp. 569-572, 2011.

[48] Lee JE, Han HR, Song H et al., "Correlates of self-care behaviors for managing hypertension among Korean Americans: a questionnaire survey," International Journal of Nursing Studies, vol. 47, no. 4, pp. 411-417, 2010.

[49]Chung ML, Moser DK, Lennie TA, Carter LW, Bentley B, Trupp R, and Armentano DS. Gender difference in adherence to sodium restriction diet in patient with heart failure. J Card Fail. 2006 Oct; 12(8): 628.

[50] Yount KM1, Agree EM, Rebellon C. Gender and use of health care among older adults in Egypt and Tunisia. Soc Sci Med. 2004 Dec; 59(12):2479-97.

[51] Weijman I, Ros WJG, Rutten GEHM, Schaufeli WB, Schabracq MJ, Winnubst JAM. The multidimensional diabetes self-managementchecklist (MDSC) (internal report). Utrecht: University Medical Center Utrecht, Section of Medical and Health Psychology; 2003.

[52] Jernat AF and Friederichs-fitzwater MM. Patients' perceived barriers to active self-management of chronic conditions. Patient edu couns. 57(3): 300-307, 2005.

[53] Health statistical year book. Riyadh, Saudi Arabia, Ministry of Health, 2009 